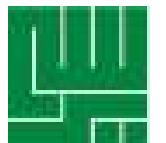

\title{
Komplikasi Kronik Aspirasi Benda Asing pada Saluran Napas Bawah
}

\section{Chronic Complication of Foreign Body Aspiration in Lower Airway}

\author{
Yandra Darusman, Oea Khairsyaf, Russilawa í \\ Bagian Pulmonologi dan Kedokteran Respirasi, Fakultas Kedokteran \\ Universitas Andalas, Padang
}

KATA KUNCI KEYWORDS

ABSTRAK
Benda asing, Komplikasi, Kronik, Atelektasis

Foreign body, Complication, Cronic, Ateletaksis

Aspirasi benda asing pada saluran napas bawah adalah kegawatdaruratan yang menyebabkan kematian. Terdapat lebih kurang 3000 kematian seetiap tahunnya akibat aspirasi benda asing di Amerika Serikat. Terdapat 14 kasus aspirasi benda asing di RSUP Persahabatan yang dilakukan tindakan bronkoskopi pada tahun 2000-2005. Penyebab tersering adalah aspirasi jarum pentul 36,7\%, kacang 21,21\% dan gigi palsu 9,09\%. Komplikasi yang terjadi karena aspirasi benda asing diantaranya pneumonia, efusi pleura, ateletaksi, abses dan hemoptisis. Seorang laki-laki 16 tahun datang dengan keluhan utama batuk produktif disertai dengan darah sejak 7 hari sebelum masuk rumah sakit. Tidak ada keluhan respirasi lain dan keluhan sistemik. Riwayat tertelan paku mading 3 bulan yang lalu, tapi tidak pernah memeriksakan diri ke dokter. Tanda-tanda vital normal. Fremitus melemah dan suara ronki di paru kanan bawah. Rontgen toraks AP-Lateral menunjukkan gambaran ateletaksis di lobus medius dan inferior paru kanan, terdapat corpus alienum di hilus kanan. CT scan toraks menunjukkan gambaran ateletaksis dan cospus alienum. Pasien didagnosis dengan ateletaksis ec corpus alienum dengan diagnosis banding abses paru. Corpus alienum dikeluarkan dengan tindakan bronkoskopi serat lentur. Tampak gambaran bronkoskopi pada rontgen toraks post bronkoskopi. Pasien diterapi dengan antibiotic dan obat anti perdarahan. Dari kasus ini dapat disimpulkan bahwa komplikasi kronik aspirasi benda asing pada saluran napas bawah diantraanya ateletaksis, abses paru dan bronkiektasi. Usia muda mempengaruhi prognosis baik, karena gejala sisa tidak ditemukan pada kasus ini. 
ABSTRACT Aspiration of foreign bodies in the lower airway is an emergency condition causes death. In the United States approximately 3000 people die each year due to aspiration of foreign bodies. There were 14 cases of foreign body aspiration in Persahabatan Hospital were performed bronchoscopy in 2000-2005. The most common causes were needles $36.37 \%$, nuts $21.21 \%$, and dentures $9.09 \%$. The complications due to foreign bodies aspiration could be pneumonia, pleural effusion, pulmonary atelectasis, abscess and hemoptysis. A man 16 years old attended with chief complaint is productive cough with blood strict since 7 days ago. There were not others respiratory and systemic complains. History of drawing pin aspiration 3 months ago, but he never checked it to the doctor. Vital signs were normal. Weakened fremitus and crakles in right lower lung. Chest $x$ ray AP-Lateral showed ateletacsis in medius and inferior lobe of right lung, and there was corpus alienum sign in right hilum. Thorax CT scan showed pneumonia pattern with ateletacsis and corpus alienum. Patient was diagnosed as right lung ateletacsis caused by corpus alienum with differential diagnosis was right lung Lung abscess. Fiber optic bronchoscopy was performed to remove a corpus alienum. Chest $x$-ray post bronchoscopy showed right lung bronchiectasis. Patient was treated with antibiotics and hemostatic drugs and discharge after 17 days hospitalization without any respiratory complaints. From this case could be concluded that chronic complications of foreign body aspiration in the lower airway could be atelectasis, lung abscess and bronchiectasis. The young age affects good prognosis, because sequelae were not found in this case.

\section{PENDAHULUAN}

Benda asing di saluran napas atau dikenal dengan aspirasi benda asing merupakan keadaan emergensi yang memerlukan penanganan segera. Keterlambatan penanganan dapat meningkatkan terjadinya komplikasi akut maupun kronik bahkan kematian (Saki N et al., 2009). Di Amerika Serikat lebih kurang 3000 orang meninggal se tiap tahunnya akibat aspirasi benda asing (Nagendran T, 1999). Secara statistik, persentase aspirasi benda asing berdasarkan letaknya masing-masing adalah; hipofaring 5\%, laring/trakea $12 \%$, dan bronkus sebanyak $83 \%$. Kebanyakan kasus aspirasi benda asing terjadi pada anak usia $<15$ tahun; sekitar $75 \%$ aspirasi benda asing terjadi pada anak usia 1-3 tahun. Rasio laki-laki banding wanita adalah 1,4:1 (Murray $A D, 2006)$.

Correspondence:
Yandra Darusman, Bagian Pulmonologi dan
Kedokteran Respirasi, Fakultas Kedokteran Universitas
Andalas, Padang
Email: usmankuchiki@gmail.com


Saat aspirasi terjadi, benda asing masuk melalui rima glotis yang sedang terbuka, sehingga masuk ke dalam trakea dan bronkus. Pada orang dewasa benda asing cenderung tersangkut pada bronkus utama kanan karena lebih segaris lurus dengan trakea dan posisi karina yang lebih besar. Sampai umur 15 tahun sudut yang dibentuk bronkus dengan trakea antara kiri dan kanan hampir sama, sehingga pada anak-anak, frekuensi lokasi tersangkut benda asing hampir sama kejadian antara bronkus utama kiri dan kanan. Lokasi tersangkut benda asing juga dipengaruhi posisi saat terjadi aspirasi (Fitri F et al., 2011). Iskandar pada laporannya di bagian THT FKUI/RS Cipto Mangunkusomo selama 4 tahun dari Januari 1990Desember 1993 mendapatkan 70 kasus aspirasi benda asing di traktus trakeobronkial. Lokasi benda asing tersering $(62,86 \%)$ di bronkus utama kanan (Iskandar N, 1994).

Di Indonesia tahun 2000-2005, khususnya di RS Persahabatan angka kejadian aspirasi benda asing pada dewasa dan anak yang dilakukan tindakan bronkoskopi adalah 14 kasus $(0,5 \%$ dari seluruh tindakan bronkoskopi). Kasus aspirasi terbanyak akibat jarum pentul 36,37\%, kacang $21,21 \%$, gigi palsu 9,09\% (Arief N, 2005). Gejala aspirasi benda asing terbagi dalam 3 fase yaitu fase awal, fase asimptomatik dan fase komplikasi. Gejala komplikasi akibat benda asing dapat berupa pneumonia, efusi pleura, atelektasis paru, abses dan hemoptisis (Novialdi et al., 2015). Pada penelitian yang dilakukan Chun-Hua dkk, komplikasi dari aspirasi benda asing adalah pneumonitis obstruktif $26 \%$, atelektasis $12 \%$, abses paru $7 \%$, bronkiektasis 5\% (Chung HC, 1997).
Setiap benda asing di saluran napas merupakan hal serius jika menyebabkan sumbatan jalan napas akut, baik total atau sebagian. Pada beberapa kasus tidak memberikan gejala khas sehingga dapat memperlambat diagnosis maupun penanganan. Diagnosis benda asing trakeobronkial dapat ditegakkan dengan anamnesis riwayat tersedak makanan, sesak napas, pemeriksaan radiologis dan dipastikan dengan bronkoskopi (Nagendran T, 1999).

\section{KASUS}

Seorang pasien laki-laki berusia 16 tahun rujukan RS Ibnu Sina Payakumbuh pada tanggal 6 Februari 2017, datang dengan keluhan utama batuk darah sejak 1 minggu sebelum masuk rumah sakit. Batuk darah lengket didahak dan bersifat hilang timbul, kemudian pasien dilakukan foto toraks pada tanggal 2 Februari 2017 dirawat selma 5 hari kemudian dirujuk ke RSUP Dr. M. Djamil Padang untuk penatalaksanaan lebih lanjut. Pada awalnya pasien terhirup paku mading 4 bulan yang lalu, namun pasien tidak berobat ke dokter. Sesak napas sejak 1 bulan yang lalu, tidak menciut, sesak napas meningkat jika beraktifitas berat atau batuk.

Batuk meningkat sejak 1 minggu yang lalu. Batuk berdahak warna putih kekuningan dan kental. Batuk-batuk sudah dirasakan sejak 4 bulan yang lalu dan bersifat hilang timbul. Nyeri dada kanan sejak 4 bulan yang lalu, tidak menjalar, bersifat hilang timbul, meningkat ketika batuk. Nyeri muncul sejak pasien terhirup paku mading. Demam tidak ada, riwayat demam 1 minggu yang lalu, tidak tinggi, tidak menggigil, bersifat hilang timbul. Keringat malam tidak ada. Penurunan 
nafsu makan sejak 1 bulan yang lalu, penurunan berat badan sejak 1 bulan yang lalu, tapi pasien tidak tahu berapa kg. Riwayat minum obat anti tuberkulosis sebelumnya tidak ada begitu juga dalam keluarga. Pasien seorang siswa kelas 2 sekolah menegah atas dan tidak merokok.

Batuk meningkat sejak 1 minggu yang lalu. Batuk berdahak warna putih kekuningan dan kental. Batuk-batuk sudah dirasakan sejak 4 bulan yang lalu dan bersifat hilang timbul. Nyeri dada kanan sejak 4 bulan yang lalu, tidak menjalar, bersifat hilang timbul, meningkat ketika batuk. Nyeri muncul sejak pasien terhirup paku mading. Demam tidak ada, riwayat demam 1 minggu yang lalu, tidak tinggi, tidak menggigil, bersifat hilang timbul. Keringat malam tidak ada. Penurunan nafsu makan sejak 1 bulan yang lalu, penurunan berat badan sejak 1 bulan yang lalu, tapi pasien tidak tahu berapa kg. Riwayat minum obat anti tuberkulosis sebelumnya tidak ada begitu juga dalam keluarga. Pasien seorang siswa kelas 2 sekolah menegah atas dan tidak merokok.

Pada pemeriksaan umum, kesadaran komposmentis kooperatif, keadaan umum sedang. Keadaan gizi sedang dengan tinggi badan $160 \mathrm{~cm}$ dan berat badan 50kg. Tekanan darah $110 / 70 \mathrm{mmHg}$, nadi $84 x /$ menit, pernapasan $24 x /$ menit, suhu $37,50 C$. Pemeriksaan fisik ditemukan konjungtiva tidak anemis, sklera tidak ikterik. Pada pasien tidak ditemukan pembedaran kelenjar kelenjar getah bening.

Pemeriksaan dada, pada inspeksi asimetris kanan lebih flat dari kiri (statis), pergerakan kanan tertinggal dari kiri (dinamis). Pada palpasi fremitus kanan melemah dari kiri. Pemeriksaan perkusi tidak dilakukan karena pasien batuk darah. Auskultasi ditemukan paru kanan dari atas sampai dengan ruang intercosta (RIC) IV suara nafas bronkovesikuler, rhonkhi positif, tidak ada wheezing, kebawah suara napas melemah sampai dengan menghilang. Pada paru kiri ditemukan suara napas bronkovesikuler rhonki positif, tidak ada wheezing.

Pada pemeriksaan laboratorium didapatkan hasil hemoglobin 12,4gr/dl, leukosit $17.810 / \mathrm{mm} 3$, hematokrit 39\%, trombosit $608.000 / \mathrm{mm} 3$, gula darah sewaktu $96 \mathrm{mg} / \mathrm{dl}$, ureum $23 \mathrm{mg} / \mathrm{dl}$, kretinin $0,7 \mathrm{mg} / \mathrm{dl}$, total protein $7,5 \mathrm{~g} / \mathrm{dl}$, albumin 3,0g/dl, globulin 4,5g/dl. Kesan laboratorium dalam batas normal.

Saat pasien datang ke IGD RS Ibnu Sina Payakumbuh dilakukan pemeriksaan foto thorak dan didapatkan foto sentris dan simetris, densitas sedang, tampak gambaran perselubungan relatif homogen dengan penyemitan sela iga dan tampak corpus alienum pada paru kanan, tampak infiltrat di perihiler paru kiri dan kanan. Kesan atelektasis, korpus alienum paru kanan dan pneumonia. Saat pasien tiba di RSUP Dr. M. Djamil Padang pasien dilakukan foto lateral tanggal 6 Februari 2017 (Gambar 1). 

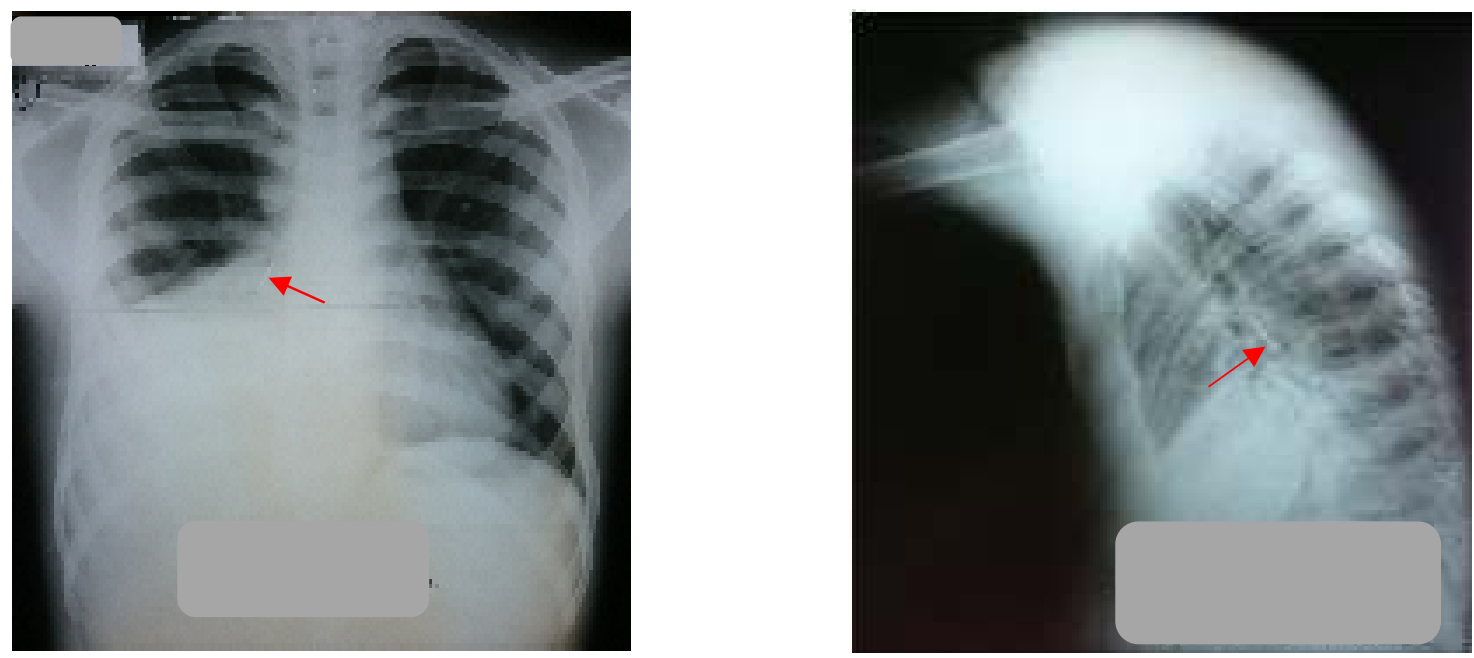

Gambar 1. Foto toraks antero lateral (RS Ibnu Sina Payakumbuh) dan lateral (RSUP DR M. Djamil Padang) sebelum bronkoskopi rigid

Pasien didiagnosis kerja dengan atelektasis dekstra ec korpus alienum dengan hemaptoe+community acquired pneumonia (CAP)+Suspek TB paru. Diagnosis banding abses paru dekstra ec corpus alienum dengan hemaptoe + community acquired pneumon (AP)+TB paru. Pasien diberi terapi IVFD $\mathrm{NaCL}$ 0,9\% 12 jam/kolf, injeksi ceftriaxone $1 \times 2$ gr (skin test), infus Levofloxacin $\quad 1 \times 750 \mathrm{mg}$, infus metronidazole $\quad 3 \times 500 \mathrm{mg}$, asam tranexamat $3 \times 500 \mathrm{mg}$ tablet, vitamin $\mathrm{K}$ 3x1 tablet, vitamin C 3x1 tablet. Selama rawatan pasien direncanakan untuk pemeriksaan bronkoskopi rigid dengan anestesi umum, kultur sputum dan sensitiviti kuman banal, BTA (basil tahan asam) sputum 3 kali dan CT scan thorak. Hasil BTA sputum 3 kali negatif. Hasil CT Scan toraks pneumonia di segmen 7, 8, 9, 10 dan pleura efusi dextra ec corpus alienum (Gambar 2).

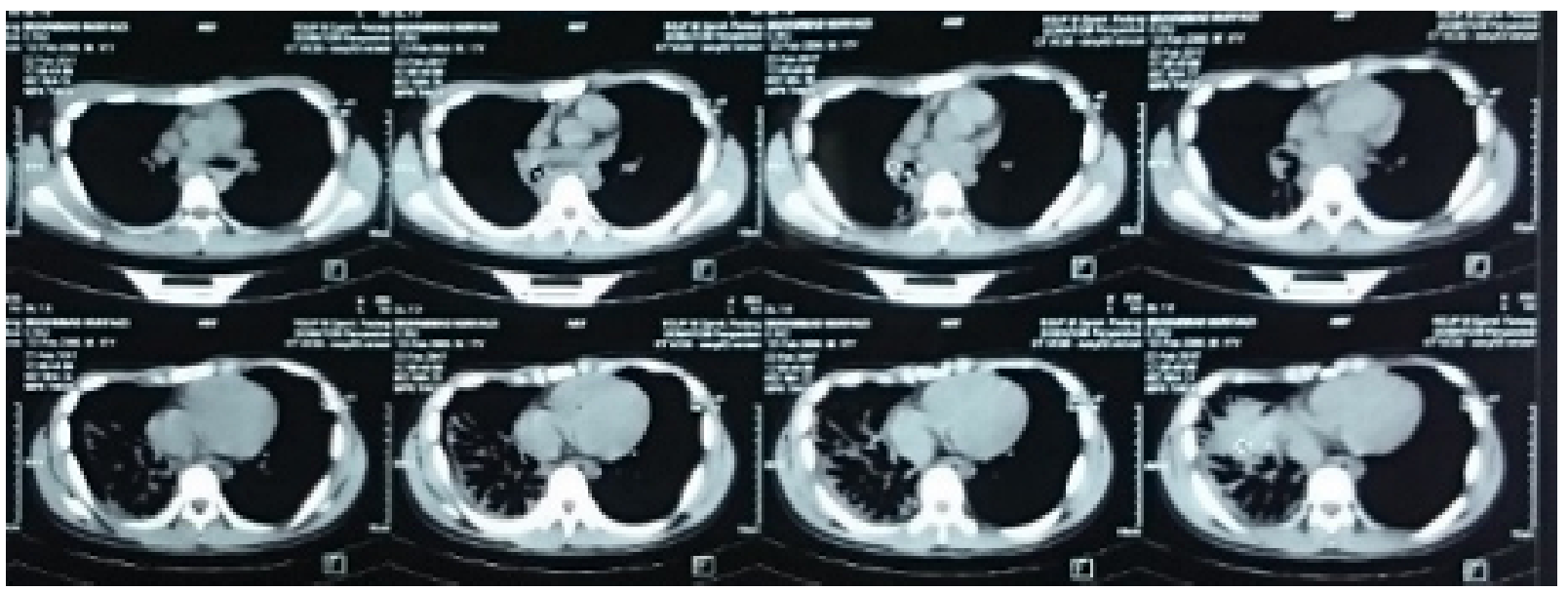

Gambar 2. CT Scan Thorak sebelum bronkoskopi rigid 
Hari rawatan ke 14 pasien dilakukan bronkoskopi dengan anestesi umum hari ini di ruang operasi. Hasil bronkoskopi dengan anestesi umum tampak korpus alienum (paku mading) di bronkus lobus bawah paru kanan. Prosedur dilakukan selama lebih kurang 1 jam 30 menit. Pada awal prosedur pasien stabil korpus alienum terlihat melalui bronkoskopi, namun korpus alienum tidak berhasil dikeluarkan karena ketika ditarik korpus alienum terlepas dan posisi sukar dilihat ditambah kondisi pasien dengan desaturasi. Prosedur dihentikan, kondisi pasien setelah bronkoskopi dengan anestesi umum stabil. Pasien direncanakan foto toraks PA (Gambar 3) dan pasien dianjurkan bronkoskopi fiber optik dengan anestesi lokal.

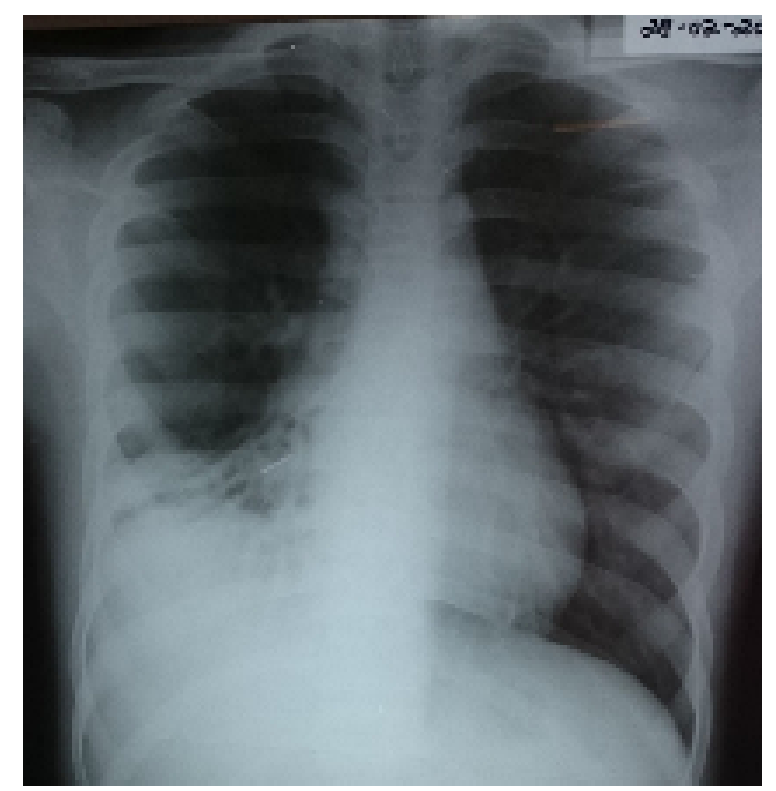

Gambar 3. Foto toraks setelah bronkoskopi rigid

Hari rawatan ke 15 batuk darah ada lengket didahak minimal, sesak napas tidak ada, demam tidak ada, batuk dahak kadang-kadang, nyeri dada dan nyeri menelan kadangkadang. Keadaan umum pasien sedang, tekanan darah 110/70 $\mathrm{mmHg}$, frekuensi nadi $82 x /$ menit, frekuensi napas 19x/menit, suhu 36,7oC. Pada pemeriksaan auskultasi dada kanan atas sampai dengan RIC IV bronkovesikuler rhonki tidak ada, wheezing tidak ada, suara napas bawah melemah, kiri suara napas bronkovesikuler, rhonki tidak ada, wheezing tidak ada. Pasien foto toraks PA, konsul jantung untuk persiapan bronkoskopi fiber optik dengan anestesi lokal. Hasil foto toraks pasien pada tanggal 02 Maret 2017 didapatkan foto sentris, tidak simetris, densitas sedang, tampak korpus alienum di lobus bawah paru kanan dan tampak gambaran honey comb appearance di lobus bawah paru kanan. Kesan korpus alienum dan bronkiektasis paru kanan. Pasien direncanakan bronkoskopi fiber optik dengan anestesi lokal dengan menggunakan forsep aligator pada hari rawatan ke 16. Hasil pemeriksaan bronkoskopi adalah korpus alienum di lobus bawah paru kanan (Gambar 4). 
Selama prosedur dilakukan pasien stabil dan korpus alienum berhasil dikeluarkan (Gambar 5). Kondisi pasien setelah bronkoskopi batuk darah tidak ada, sesak napas tidak ada, demam tidak ada, ada, batuk dahak kadangkadang, nyeri dada tidak ada. Keadaan umum pasien sedang, tekanan darah
$130 / 80 \mathrm{mmHg}$, frekuensi nadi 99x/menit, frekuensi napas 22x/menit, suhu 36,6oC. Pada pemeriksaan auskultasi dada kanan atas sampai dengan RIC IV bronkovesikuler rhonki ada dibasal, wheezing tidak ada, kiri suara napas bronkovesikuler, rhonki tidak ada, wheezing tidak ada.

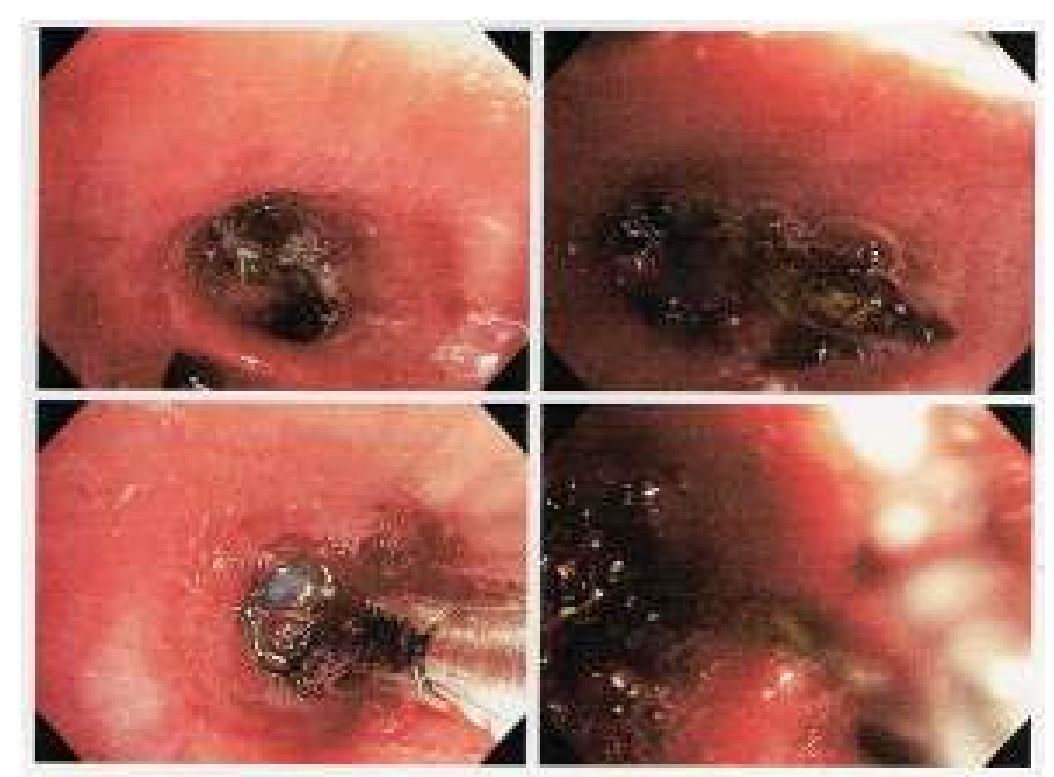

Gambar 4. Bronkoskopi fiber optik dengan forcep alligator

Hari rawatan ke 17 batuk darah tidak ada, sesak napas tidak ada, demam tidak ada, batuk kadangkadang dahak tidak ada, nyeri dada tidak ada. Keadaan umum pasien baik, tekanan darah $110 / 80 \mathrm{mmHg}$, frekuensi nadi $89 x /$ menit, frekuensi napas 19x/menit, suhu $36,8^{\circ} \mathrm{C}$. Pada pemeriksaan auskultasi dada kanan atas sampai dengan RIC IV bronkovesikuler rhonki ada dibasal minimal, wheezing tidak ada, kiri suara napas bronkovesikuler, rhonki tidak ada, wheezing tidak ada. Pasien direncanakan foto toraks PA setelah bronkoskopi fiber optik pengeluaran benda asing.

Hasil rontgen foto thorak post bronkoskopi pengeluaran korpus alienum, foto sentris, simetris, densitas keras, tampak honey comb appearance di lobus bawah paru kanan. Kesan bronkiektasis paru kanan (Gambar 6). Pasien dibolehkan pulang dengan diagnosis bronkiektasis ec. korpus alienum pada hari rawatan ke 18. Pasien dianjurkan untuk kontrol poli paru dan akan direncanakan CT Scan toraks setelah bronkoskopi fiber optik pengeluaran benda asing. 


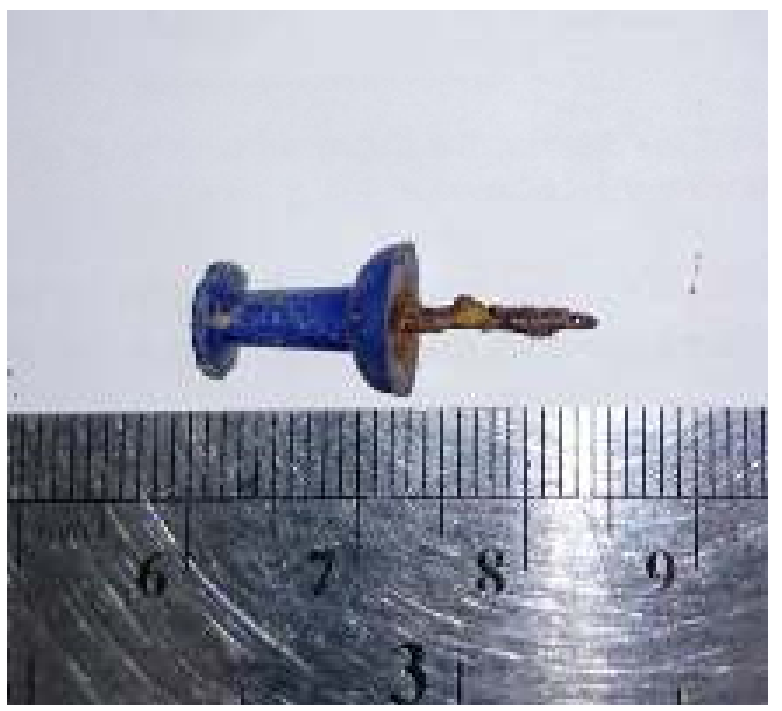

Gambar 5. Benda asing yang berhasil dikeluarkan

Pasien kontrol poli paru RSUP Dr. Djamil Padang dengan kondisi pasien batuk darah tidak ada, sesak napas tidak ada, demam tidak ada, batuk tidak ada, nyeri dada tidak ada. Pada pemeriksaan auskultasi dada kanan atas sampai dengan RIC IV bronkovesikuler rhonki ada dibasal minimal, wheezing tidak ada, kiri suara napas bronkovesikule nki ada, wheezing tidak ada. Pasien dilakukan pemeriksaan CT scan toraks setelah bronkoskopi fiber optik pengeluaran benda asing. Hasil CT scan toraks dengan kesan bronkiektasis terinfeksi paru kanan (Gambar 7). Pasien ditegakkan diagnosis akhir bronkiektasis dekstra ec korpus alienum. Pasien dianjurkan kontrol bila ada keluhan.

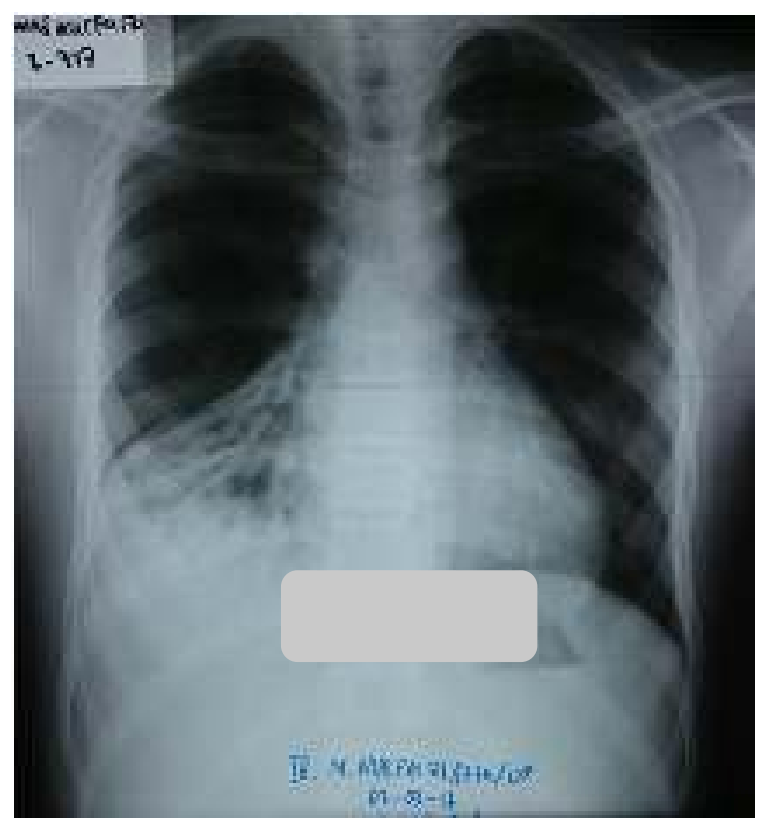

Gambar 6. Foto toraks setelah benda asing dikeluarkan 


\section{DISKUSI}

Pada kasus ini terjadi aspirasi benda asing anorganik tajam dengan lokasi pada bronkus kanan. Jenis benda asing yang terinhalasi bisa bermacammacam bentuk, benda asing organik lebih sering ditemukan dari pada benda asing anorganik. Tingkat keparahan, tanda dan gejala dari aspirasi benda asing tergantung kepada tempat, ukuran, komposisi dan lama nya benda asing berada di saluran napas (Manish VJ et al., 2016). Salah MT dkk pada penelitiannya mendapatkan presentase lokasi benda asing yaitu hipofaring $(5 \%)$, laring/trakea (12\%) dan yang tersering di bronkus (83\%). Bronkus utama kanan merupakan terbanyak yaitu (43\%), bronkus utama kiri (24\%), segmen bronkus kanan (22\%) dan segmen bronkus kiri (11\%) (Salah MT et al., 2007). Bronkus utama kanan merupakan tempat yang paling sering tersangkut oleh benda asing bila teraspirasi dikarenakan bronkus utama kanan lebih vertikal dibanding bronkus utama kiri (Manish VJ et al., 2016).

$$
\text { Pasien telah dilakukan }
$$

anamnesis didapatkan batuk darah sejak 1 minggu yang lalu, lengket didahak. Pasien mengaku awalnya terhirup paku mading sejak 4 bulan yang lalu namun tidak pernah mendapatkan penanganan medis. Keluhan pasien tersebut sesuai dengan kepustakaan bahwa batuk darah dapat ditemukan pada pasien aspirasi benda asing yang telah masuk ke dalam fase komplikasi (Warshawsky ME. 2004). Keluhan pasien yang lain adalah batukbatuk yang sudah dirasakan pasien sela selama 4 bulan sejak terhirup paku mading. Gejala ini juga sesuai dengan kepustakaan bahwa gejala yang tersering dari aspirasi benda asing adalah batuk sebanyak 68,3\%. Penderita dengan benda asing di bronkus umumnya datang pada fase asimptomatik.

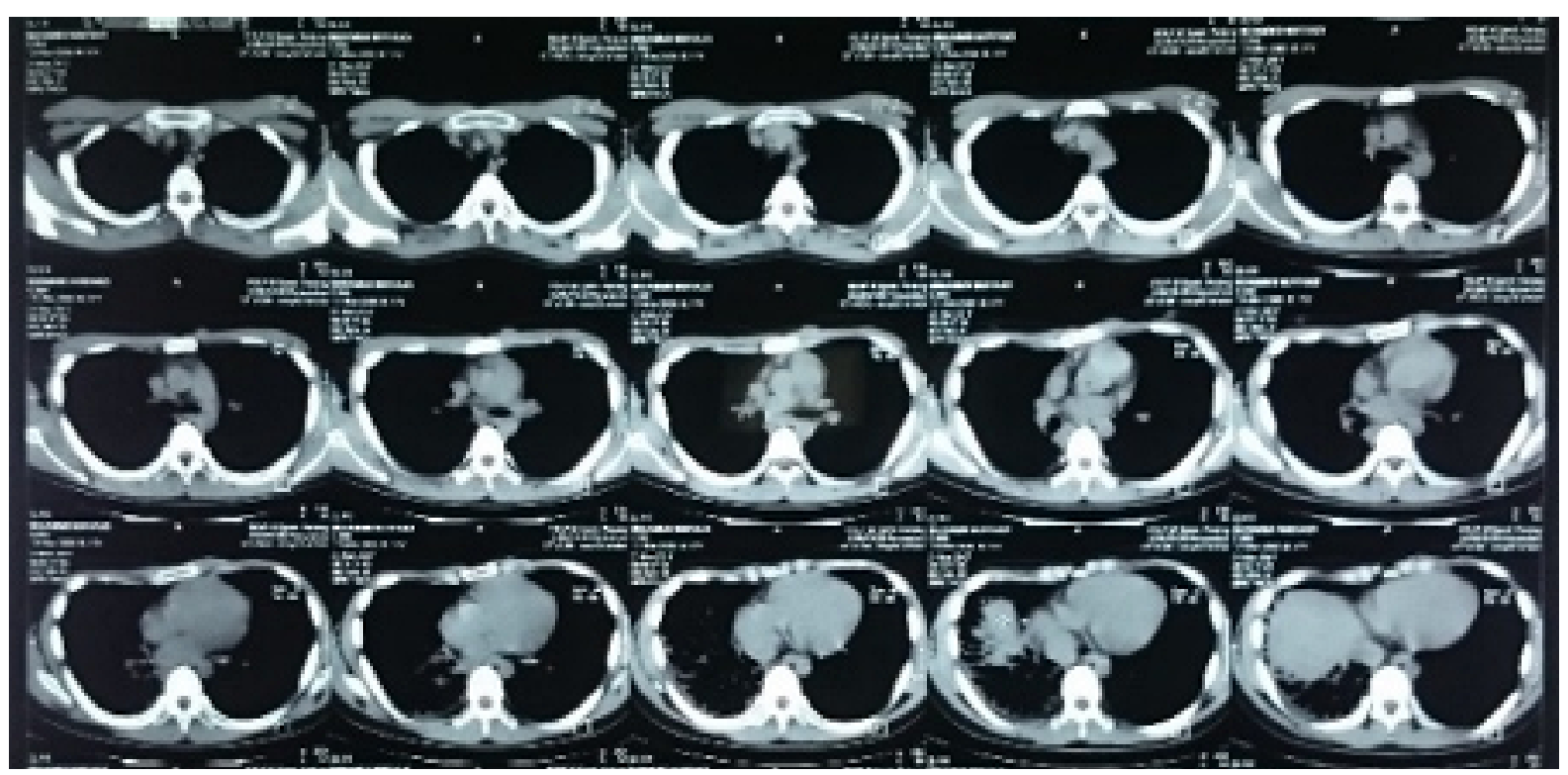

Gambar 7. CT Scan toraks setelah bronkoskopi fiber optik dengan forsep alligator 
Pada fase ini keadaan umum penderita masih baik dan foto toraks belum memperlihatkan kelainan. Pada fase pulmonum, benda asing di bronkus utama atau cabang-cabangnya akan menimbulkan gejala batuk yang lama. Pneumonia merupakan salah satu komplikasi akibat benda asing untuk waktu yang lama, pada pasien ini juga ditemukan gejala batuk meningkat sejak 1 minggu yang lalu, batuk berdahak warna putih kekuningan dan kental (Doody DP, 2004).

Pemeriksaan fisik pada pasien ini yaitu kesadaran komposmentis kooperatif, keadaan umum sedang, tekanan darah 110/70mmHg, nadi $84 \mathrm{x} /$ menit, pernapasan $24 \mathrm{x} /$ menit, suhu $37,5^{\circ} \mathrm{C}$. Pemeriksaan dada, pada inspeksi asimetris kanan lebih flat dari kiri (statis), pergerakan kanan tertinggal dari kiri (dinamis). Pada palpasi fremitus kanan melemah dari kiri. Pemeriksaan perkusi tidak dilakukan karena pasien batuk darah. Auskultasi ditemukan paru kanan dari atas sampai dengan RIC IV suara napas bronkovesikuler, rhonkhi positif, tidak ada wheezing, kebawah suara napas melemah sampai dengan menghilang. Pada paru kiri ditemukan suara napas bronkovesikuler rhonkhi positif, tidak ada wheezing. Pasien telah dilakukan pemeriksaan foto toraks tampak gambaran perselubungan relatif homogen dengan penyemitan sela iga dan tampak korpus alienum pada paru kanan, tampak infiltrat di perihiler paru kiri dan kanan. Kesan atelektasis, korpus alienum paru kanan dan pneumonia.

Diagnosis aspirasi benda asing selain berdasarkan anamnesis dan pemeriksaan fisik dibutuhkan juga pemeriksaan radiologi. Pada pemeriksaan radiologi kasus aspirasi benda asing dapat ditemukan gambaran benda asing yang radio-opak dan sering didapatkan adanya gambaran infeksi paru, udara yang terperangkap dan atelektasis pada aspirasi benda asing lama. Sekitar $24 \%$ pasien yang dilakukan pemeriksaan radiologi tidak menunjukkan kelainan paru walupun sudah dilakukan bronkoskopi (Merchant SN et al., 1984). Pada kasus benda asing paku ini mudah didiagnosis dengan menggunakan rontgen foto torak karena benda asing berasal dari logam sehingga gambaran radiologi berupa gambaran radio-opak.

Pasien ini didiagnosis kerja dengan atelektasis dekstra dikarenakan korpus alienum dengan hemaptoe disertai community acquired pneumonia (CAP) dan Suspek TB paru. Diagnosis banding abses paru dekstra dikarenakan korpus alienum dengan hemaptoe serta community acquired pneumonia (CAP) dan TB paru. Pasien diberi terapi kombinasi 3 antibiotik selain anti perdarahan dikarenakan komplikasi dari aspirasi benda asing dapat berupa pneumonia juga abses paru sering dengan mix infection, hal ini sesuai dengan anamnesis, pemeriksaan fisik dan pemeriksaan rontgen foto thorak. Selama rawatan pasien direncanakan untuk pemeriksaan bronkoskopi rigid dengan anestesi umum, kultur sputum dan sensitivitas kuman, BTA sputum dan CT scan toraks. BTA sputum dilakukan karena pasien didiagnosis dengan suspek tb paru, sedangkan hasil BTA sputum pada pasien ini adalah negatif. Hasil pemeriksaan kultur sputum dan sensitivitas kuman pada pasien ini adalah ditemukan jenis bakteri Staphylococcus aureus dan telah diberi terapi antibiotik yang sesuai dengan hasil kultur. 
Pasien juga telah dikonsulkan ke bagian bedah thorak untuk kemungkinan thorakotomi apabila bronkoskopi rigid dengan anestesi umum gagal mengeluarkan benda asing yang teraspirasi. Advis dari bagian bedah adalah anjuran CT Scan toraks bila thorakotomi akhirnya dilakukan. Pasien telah dilakukan pemeriksaan CT Scan toraks sebelum dibronkoskopi dengan hasil pneumonia di segmen 7,8 , 9, 10 dan pleura efusi dextra dan korpus alienum. Hasil CT Scan toraks setelah bronkoskopi dengan kesan bronkiektasis terinfeksi paru kanan. Hal ini sesuai dengan kepustakaan bahwa komplikasi akibat benda asing, dapat berupa empisema obstruktif, pneumonia, bronkiektasis, atelektasis, abses paru dan hemoptisis (Warshawsky ME, 2004). Bronkiektasis merupakan komplikasi kronik yang paling penting dari aspirasi benda asing dan memungkinkan diperlukan penanganan operasi pada beberapa kasus dengan hemaptoe dan infeksi yang sering berulang. Lokasi bronkiektasis lebih sering terlokalisir dibandingkan proses difus. Bronkiektasis dapat terbentuk dalam beberapa tahun setelah aspirasi benda asing. Meskipun hanya operasi yang merupakan terapi kuratif pada bronkiektasis, beberapa literatur melaporkan bahwa bronkiektasis dan atau dilatasi bronkus sekunder dikarenakan aspirasi benda asing mengalami resolusi setelah beberapa lama tindakan pengeluaran benda asing dilakukan (Oner D et al., 2002).

Bronkoskopi rigid dengan anestesi umum merupakan standar baku emas untuk mengeluarkan benda asing di trakeobronkial dengan aman (Zhang Y, and Zhang Z, 2001). Pada pasien ini telah dilakukan bronkoskopi rigid dengan anestesi umum namun benda asing tidak berhasil dikeluarkan dan kondisi pasien tidak memungkinkan dilakukan prosedur lebih lama lagi dikarenakan penurunan saturasi. Pasien juga tidak jadi dilakukan thorakotomi. Tindakan bedah pada kasus aspirasi benda asing jarang dilakukan, namun bila bronkoskopi rigid dengan anestesi umum gagal dilakukan tindakan pembedahan dipertimbangkan untuk dilakukan. Pasien ini terdapat aspirasi benda asing yang lama juga dengan hemaptoe dan atelektasi yang mana merupakan komplikasi kronik dari aspirasi benda asing merupakan indikasi dilakukan tindakan pembedahan (Manish VJ et al., 2016). Pasien tetap dilakukan tindakan invasif yang lebih aman yaitu dengan bronkoskopi fleksibel fiber optik dengan menggunakan forsep aligator dengan anestesi lokal. Penilitian Athanassiadi dkk mendapatkan bahwa $36 \%$ pasien dilakukan tindakan torakotomi dikarenakan benda asing yang berpindah terlalu jauh kedalam bronkus atau penggunaan bronkoskopi rigid yang gagal dalam mengeluarkan benda asing (Athanassiadi K et al., 2000). Pada penelitian lain yang dilakukan oleh Konrad dkk menyatakan bahwa tindakan torakotomi dilakukan setelah prosedur bronkoskopi fleksibel fiber optik gagal mengeluarkan aspirasi benda asing (Konrad P et al., 2011).

Saat dilakukan prosedur bronkoskopi rigid pasien juga mengalami penurunan saturasi oksigen. Menurut Lukomsky (Mangape et al., 1987) bahwa komplikasi tindakan bronkoskopi terbagi dua: Komplikasi minor berupa perlukaan mukosa faring, laringitis akut, hipoksia, perdarahan sedang dan demam; Komplikasi mayor 
berupa tension pneumothorak, perdarahan hebat, hipoksia berat sampai kegagalan jantung. Sedangkan menurut Cassol dkk komplikasi akibat tindakan bronkoskopi terbagi menjadi dua, yaitu: Komplikasi minor, seperti adanya desaturasi oksigen dan; Komplikasi mayor seperti laringospasme dengan desaturasi, laringospasme dengan bradikardi, laringobronkospasme dengan bradikardi dan pneumotorak bilateral. Rontgen foto torak ulang pascaoperasi perlu dilakukan untuk menilai jaringan submukosa longgar pada daerah subglotis yang dapat memberikan reaksi terhadap trauma kecil (Cassol V et al., 2003). Pasien telah dilakukan foto rontgen thorak post bronkoskopi untuk evaluasi dengan kesan bronkiektasis paru kanan bawah.

Saat pasien dipulangkan, diperlukan evaluasi malaui CT scan toraks post bronkoskopi untuk menilai lebih dalam apakah terdapat komplikasi post bronkoskopi setelah benda asing dikeluarkan. Pasien telah dilakukan CT scan toraks post bronkoskopi dari Poli Paru RSUP Dr M. Djamil Padang dengan kesan bronkiektasis terinfeksi paru kanan.

\section{KESIMPULAN}

Timbulnya komplikasi aspirasi benda asing pada saluran nafas tergantung pada jenis, ukuran, bentuk dan posisi benda asing pada saluran nafas. Waktu munculnya komplikasi tergantung dari derajat atau tipe obstruksi yang ditimbulkan oleh benda asing teraspirasi. Tipe obstruksi total dari benda asing terhadap lumen saluran napas menyebabkan kolapsnya jaringan paru (atelektasis). Pada pasien aspirasi benda asing yang kronik, hemaptoe, bronkiektasis, infeksi saluran napas (pneumonia akut atau berulang, abses paru) merupakan gejala klinis yang paling banyak ditemukan. Tindakan pembedahan dilakukan bila seluruh tindakan lebih kurang invasif telah dilakukan.

\section{KEPUSTAKAAN}

Athanassiadi K et al., 2000. Management of foreign bodies in the tracheobronchial tree in adults: a 10year experience. Eur J Surg. 166: 920923.

Cassol V et al., 2003. Foreign Body in Children's Airways. J.Pneumologia. 29:1-10.

Doody DP. 2004. Foreign body aspiration. In Grillo HC editors. Surgery of the trachea and bronchi. London: BC Decker Inc,p 707-17.

Fitri F, Pulungan MR 2011. Ekstraksi benda asing (kacang tanah) di bronkus dengan bronkoskop kaku. Majalah Kedokteran Andalas. 35(1): 68-80.

Iskandar $\mathrm{N}$ 1994. Ingested and inhaled foreign bodies. In Dr. Cipto Mangunkusumo Hospital, Jakarta, Indonesia. Med J ORLI. 25: 311-8.

Konrad P et al., 2011. Foreign bodies in the tracheobronchial tree in adults. Kardiochirurgia i Torakochirurgia Polska. 8 (2): 220-224.

Mangape D and Asbudi 1987. Bronkoskopi kaku. Dalam: Lokakarya Endoskopi, Ujungpandang. Desember.

Manish VJ et al., 2016. Late Presentation of Bronchial Foreign Body inYoung Adult: A Case Report. Scientific Research Publishing J. 5: 302-7.

Merchant SN et al., 1984. Foreign bodies in the bronchi (a 10 year review of 132 cases). J of Postgraduate Med. 30 (4):219-23.

Murray AD 2006. Foreign bodies of airway. [Online]. 2006. [Cited 2017 Maret 18].Available at http://emedicine. 
medscape.com/article/872498overview.

Nagendran T 1999. Management of foreign bodies in the emergency departement. Hospital Phisician. 9: 27-40.

Novialdi, Fitri F, Subroto H 2015. Aspirasi benda asing paku dengan komplikasi atelektasis paru dan aspirasi benda asing jarum pentul tanpa komplikasi. Jurnal Kesehatan Andalas. 4(2): 626-38.

Oner D et al., 2002. Foreign body aspiration: clinical utility of flexible bronchoscopy. Postgrad Med J. 78: 399-403

Saki N, Nikakhlagh S, Rahim F, Abshirini H 2009. Foreign body aspiration in infancy: A 20-year experience. Int J Med Sci 2009; 6: 322-8.

Salah MT et al., 2007. Delayed diagnosis of foreign body aspiration in children. Sudanese Journal of Public Health. 2 (1):48-50.

Warshawsky ME 2004. Foreign Body Aspiration. Diakses dari: www.emedicine.com/article/298940.

Zhang, Y. and Zhang, Z 2001. Management of Irregular Shaped Airway Foreign Body in Children. Chinese Journal of Otorhinolaryngology. 36, 231-234. 